\title{
A Proposal for the Performance, Classification, and Reporting of Lymph Node Fine-Needle Aspiration Cytopathology: The Sydney System
}

\author{
Mousa A. Al-Abbadi ${ }^{a}$ Helena Barroca ${ }^{b}$ Beata Bode-Lesniewska ${ }^{c}$ \\ Maria Calaminicid $^{d}$ Nancy P. Caraway ${ }^{e}$ David F. Chhieng ${ }^{f}$ Immacolata Cozzolino $^{g}$ \\ Mats Ehinger $^{\mathrm{h}}$ Andrew S. Field ${ }^{\mathrm{i}-\mathrm{k}}$ William R. Geddie ${ }^{1, m}$ Ruth L. Katz ${ }^{\mathrm{n}}$ Oscar Lin ${ }^{\circ}$ \\ L. Jeffrey Medeiros ${ }^{p}$ Sara E. Monaco ${ }^{q}$ Arvind Rajwanshi ${ }^{r}$ Fernando C. Schmitt ${ }^{s}$ \\ Philippe Vielh ${ }^{t}$ Pio Zeppa ${ }^{\mathrm{u}}$
}

${ }^{a}$ Department of Pathology, Microbiology and Forensic Medicine, the University of Jordan, Amman, Jordan; b Serviço

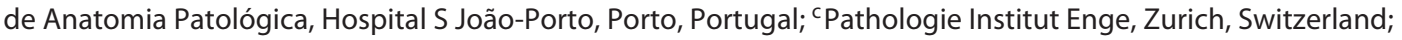
${ }^{\mathrm{d}}$ Department of Cellular Pathology, Barts Health NHS Trust and Centre for Haemato-Oncology, Barts Cancer Institute, Queen Mary University of London, London, UK; ${ }^{~}$ Department of Anatomic Pathology, the University of Texas MD Anderson Cancer Center, Houston, TX, USA; ${ }^{f}$ Department of Pathology, University of Washington Medical Center, Seattle, WA, USA; 9 Pathology Unit, Department of Mental and Physical Health and Preventive Medicine, University

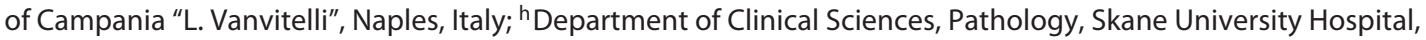
Lund University, Lund, Sweden; 'University of NSW Medical School, Sydney, NSW, Australia; 'University of Notre Dame Medical School, Sydney, NSW, Australia; ' Department of Anatomical Pathology, St Vincent's Hospital, Sydney, NSW, Australia; 'University Health Network, UHN, Toronto, ON, Canada; ${ }^{m}$ Department of Laboratory Medicine and Pathobiology, University of Toronto, Toronto, ON, Canada; ${ }^{\mathrm{n}}$ Tel HaShomer Hospital, Tel Aviv, Israel; ${ }^{\circ}$ Department of Pathology, Memorial Sloan Kettering Cancer Center, New York, NY, USA; ${ }^{P}$ Department of Hematopathology, the University of Texas MD Anderson Cancer Center, Houston, TX, USA; ${ }^{9}$ Department of Pathology, University of Pittsburgh Medical Center, Pittsburgh, PA, USA; r Department of Cytopathology and Gynecologic Pathology, Postgraduate

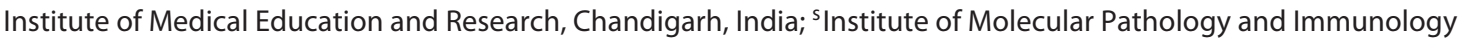
of Porto University (IPATIMUP), Instituto de Investigação e Inovação em Saúde and Medical Faculty, University of Porto, Porto, Portugal; ${ }^{\mathrm{t}}$ Medipath and American Hospital of Paris, Paris, France; " Department of Medicine and Surgery, Università degli Studi di Salerno, Fisciano, Salerno, Italy

\section{Keywords}

Lymph node $\cdot$ Fine-needle aspiration cytology $\cdot$ Reporting system

\section{Abstract \\ Background: The evaluation of lymph nodes (LN) by fine- needle aspiration cytology (FNAC) is routinely used in many institutions but it is not uniformly accepted mainly because}

of the lack of guidelines and a cytopathological diagnostic classification. A committee of cytopathologists has developed a system of performance, classification, and reporting for LN-FNAC. Methods: The committee members prepared a document that has circulated among them five times; the final text has been approved by all the participants. It is based on a review of the international literature and on the expertise of the members. The system integrates clinical and imaging data with cytopathological features and ancillary

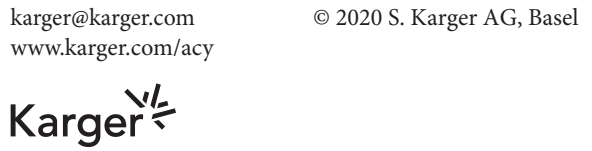


techniques. The project has received the endorsement and patronage of the International Academy of Cytology and the European Federation of the Cytology Societies. Results: Clinical, imaging, and serological data of lymphadenopathies, indications for LN-FNAC, technical procedures, and ancillary techniques are evaluated with specific recommendations. The reporting system includes two diagnostic levels. The first should provide basic diagnostic information and includes five categories: inadequate/insufficient, benign, atypical lymphoid cells of undetermined/uncertain significance, suspicious, and malignant. For each category, specific recommendations are provided. The second diagnostic level, when achievable, should produce the identification of specific benign or malignant entities and additional information by utilizing ancillary testing. Conclusion: The authors believe that the introduction of this system for performing and reporting LN-FNAC may improve the quality of the procedure, the report, and the communication between cytopathologists and the clinicians. This system may lead to a greater acceptance and utilization of LN-FNAC and to a better interdisciplinary understanding of the results of this procedure.

(c) 2020 S. Karger AG, Basel

\section{Introduction}

The evaluation of lymph nodes (LN) by fine-needle aspiration cytology (FNAC) has been routinely used as an initial diagnostic tool for many years at many institutions. $\mathrm{LN}$ are among the most common sites targeted by FNAC. In both the adult and pediatric setting, LN-FNAC can assess whether lymphadenopathy (LAP) is benign or malignant and provide staging information in patients with an established diagnosis of malignancy. LN-FNAC can be performed to relieve anxiety and provide material for microbial cultures and reduce unnecessary surgery.

The current WHO classification of lymphoproliferative disorders [1] incorporates clinical, morphological, and ancillary data that are required for specific diagnoses. LN-FNAC can provide cytomorphological information and material for ancillary testing that is diagnostic, highlighting the key role of FNAC and other small biopsies in the evaluation of LAP. Despite the tremendous progress made in performing and interpreting LN-FNAC and its correlation with ancillary tests [2-8], the technique is not uniformly accepted by clinicians and pathologists [9-11]. This is mainly due to the lack of widely shared and accepted guidelines and a cytopathological classification that directly relates to management. A consensus on a diagnostic classification system is required to improve
LN-FNAC reliability, efficiency, reproducibility of diagnoses, and acceptance by clinicians and pathologists.

However, taking into account the wide spectrum and complexity of pathology presenting in LN [1], the resulting cytopathology, and required ancillary techniques, a simple classification system similar to those used for the thyroid gland, urine, or salivary gland FNAC is not adequate for LN-FNAC. At the same time, the clinical contexts and indications to perform LN-FNAC vary greatly and the technical procedures and testing are not equally available in different institutions and different countries.

In this setting, after an intense online exchange of views and opinions, a steering committee of international cytopathologists involved in LN-FNAC met at the International Cytology Congress in May 2019 in Sydney, Australia, and decided to develop a system for reporting LN-FNAC. This proposed system, based on a review of the international literature and on the expertise of the committee members, integrates clinical and imaging information with key diagnostic cytopathological features and ancillary techniques, and is linked to a management algorithm, including options, which reflects the varying medical infrastructure available internationally. The steering committee will be expanded to include other cytopathologists as a writing team, and the proposal will be further assessed through a web-based survey to incorporate an international perspective. In 2019, the present project received the endorsement and patronage of the International Academy of Cytology during the IAC Sydney Congress and the European Federation of the Cytology Societies during the EFCS Congress in Malmo, Sweden. Further patronages and endorsements will be requested to other international and continental representative scientific cytology societies. A survey on the questions that deal with the proposed classification system and interpretative criteria for LN-FNAC will be proposed by an online survey in the next months.

\section{Aims of the Proposed LN Consensus System}

The proposed system for reporting LN-FNAC cytopathology has the following aims.

- Provide consensus guidelines and a framework of reference to facilitate communication among cytopathologists, hematopathologists, clinicians, surgeons, and other healthcare providers.

- Define and identify LN-FNAC indications, preferred operators, recommended performance, analytical and preanalytical issues, technical and diagnostic limita- 
Table 1. LN-FNAC: clinical assessment and indications

\begin{tabular}{|c|c|c|}
\hline LN-FNAC issues & Significant data & Course of action \\
\hline \multirow{2}{*}{$\begin{array}{l}\text { Clinical context for requesting } \\
\text { LN-FNAC }\end{array}$} & Single or multiple LN with no relevant history & Mandatory \\
\hline & Single or multiple LN in known pathology & Mandatory \\
\hline \multirow{3}{*}{$\begin{array}{l}\text { Clinical data to review when } \\
\text { interpreting LN-FNAC }\end{array}$} & Age, symptoms, site, size, time of onset, imaging (US) & Mandatory \\
\hline & Remote and current medical history & Mandatory \\
\hline & Basic serology (ESR, LDH, ToRCH complex, ANA, others) & Recommended \\
\hline \multirow[t]{4}{*}{ Goals of performing LN-FNAC } & $\begin{array}{l}\text { LN identification: LN or not-LN (H\&N area), atypical sites (intercostal, } \\
\text { intra-mammary, epitrochlear, intra-parotid, retroperitoneal), others }\end{array}$ & Recommended \\
\hline & $\begin{array}{l}\text { LN diagnosis to prove or exclude malignancy, and avoid LN excision for } \\
\text { benign/reactive processes }\end{array}$ & Recommended \\
\hline & Diagnosis and staging of lymphoma or metastasis & Recommended \\
\hline & Diagnosis and microbial culture material for infectious etiologies & Suggested \\
\hline
\end{tabular}

LN, lymph node; US, ultrasound; ESR, erythrocyte sedimentation rate; LDH, lactate dehydrogenase; ToRCH, toxoplasmosis rubella cytomegalovirus herpes; ANA, antinuclear antibodies.

tions, as well as the basic diagnostic reporting categories and additional diagnostic information that can produce specific disease subtyping when possible.

- Provide the key diagnostic cytopathological features of lesions that occur commonly in the various categories.

- Provide recommendations on the components of standardized diagnostic reports with the aim to improve reporting and communication between cytopathologists and clinicians.

- Provide management recommendations linked to the reporting categories with possible options that include the use of clinical and imaging follow-up, ancillary testing, and possible need of LN excision.

- Foster cytohistopathological correlations, cell storage, and research on neoplastic and non-neoplastic LN specimens.

- Increase LN-FNAC reliability and clinician awareness of its diagnostic potential.

\section{LN-FNAC Request}

The initial request for LN-FNAC typically originates from the clinician after they have examined the patient. The type of request can vary depending on the specialty of the referring clinician and also the ancillary techniques available at various institutions. In addition to an accurate diagnosis, general practitioners may be interested in the confirmation that the nodule and/or swelling are actually LN. Head and neck surgeons and otorhinolaryngologists may similarly be interested in this anatomical confirmation and in a report that directly addresses specific regional lesions. Interventional endoscopists may require specific answers for a potential pathology in mediastinal LN. Hematologists are usually interested in the diagnosis of a suspected lymphoproliferative process and posttherapy changes. Pediatricians and general practitioners often require a minimally invasive diagnosis of expected reactive processes, while avoiding an open biopsy, and this diagnosis will relieve the concerns of patients and parents. Therefore, cytopathologists dealing with LN-FNAC should be aware of the specific clinical contexts affecting LN-FNAC performance and understand the questions that the FNAC is expected to answer. The clinical data, goals, and indications for LN-FNAC are summarized in Table 1.

\section{Clinical, Imaging, and Serological Evaluation of Lymphadenopathy}

Clinical evaluation of patients with LAP may be a complex task for clinicians. Medical history and physical examination often suggest the cause of LAP and, in most cases with a clear clinical context, the diagnosis and management of reactive LAP is quite straightforward. In 
Table 2. LN US features

\begin{tabular}{|c|c|c|c|}
\hline Size & Variable & Large & Large \\
\hline Border & Regular/sharp & $\begin{array}{l}\text { Irregular, ill-defined, blurred, } \\
\text { angular, capsule infiltration }\end{array}$ & Regular/sharp \\
\hline $\begin{array}{l}\text { Structural changes: cortical } \\
\text { nodules, necrosis (coagulative, } \\
\text { cystic), reticulation, calcification, } \\
\text { matting }\end{array}$ & $\begin{array}{l}\text { Generally absent (cystic } \\
\text { necrosis, calcification and } \\
\text { matting may occur in } \\
\text { bacterial, fungal or TBC) }\end{array}$ & May be present & May be present \\
\hline $\begin{array}{l}\text { Color Doppler } \\
\text { US }\end{array}$ & $\begin{array}{l}\text { Low density, normal } \\
\text { vascular-hilar pattern, no } \\
\text { neoangiogenesis } \\
\text { Resistive index }(\mathrm{RI})<0.8 \\
\text { Pulsatility index }(\mathrm{PI})<1.6\end{array}$ & $\begin{array}{l}\text { High density, mixed vascular } \\
\text { pattern, split, tortuous arteries } \\
\text { RI }>0.8 \\
\text { PI }>1.6\end{array}$ & $\begin{array}{l}\text { High density } \\
\text { High vascular pattern no } \\
\text { preserved hilar and } \\
\text { peripheral vessels } \\
\text { RI }>0.75 \\
\text { PI }>0.75\end{array}$ \\
\hline Elastography & Normal architecture & $\begin{array}{l}\text { Focal infiltration, relatively } \\
\text { harder }\end{array}$ & $\begin{array}{l}\text { Normal but asymmetric } \\
\text { architecture }\end{array}$ \\
\hline $\begin{array}{l}\text { Contrast enhanced } \\
\text { US }\end{array}$ & $\begin{array}{l}\text { Homogeneous enhancement } \\
\text { from the hilum, centrifugal } \\
\text { enhancement }\end{array}$ & $\begin{array}{l}\text { Centripetal, different intranodal } \\
\text { enhancement levels } \\
\text { Inhomogeneous washout, } \\
\text { perfusion defects }\end{array}$ & $\begin{array}{l}\text { Intense homogeneous } \\
\text { enhancement, diffuse bright } \\
\text { spots, peripheral hypo- or } \\
\text { no enhancement }\end{array}$ \\
\hline
\end{tabular}

other cases, the cause of LAP is unclear because the clinical presentation and the response to therapy are non-specific.

The etiology of LAP correlates with patient age and clinical history, and the clinical relevance of LAP varies between adults and children [12]. LAP malignancy rates increase with age and the size of the LN. Metastatic cancers are diagnosed in $4 \%$ of patients with unexplained LAP aged $>40$ years versus $0.4 \%$ of those $<40$ years [13].

Abnormal LN are typically defined by size, consisten$c y$, and/or imaging findings. For example, LAP typically involves enlarged LN defined as greater than $1 \mathrm{~cm}$ in the largest dimension, but at specific sites, such as the supraclavicular, popliteal, iliac, and epitrochlear region, LN greater than $0.5 \mathrm{~cm}$ are considered abnormal (Table 1). Palpation of enlarged LN may suggest a pathologic process, such as soft fluctuant LN suggesting infection or firm to hard LN suggesting a malignant neoplasm. The etiologies of LAP can be easily memorized by means of the MIAMI acronym: malignancies, infections, autoimmune disorders, miscellaneous and unusual conditions, and iatrogenic causes $[14,15]$.

Imaging evaluation, particularly by ultrasound (US), is a key tool for the initial evaluation of LN (Table 2), as well as to guide FNAC of non-palpable or challenging lesions. US devices have become less expensive and portable, thus more available in hospitals and used more often in pathologist-performed FNACs. Conventional B-mode US (transcutaneous and endoscopic) provides key information on the size and site of LN, and other size-independent criteria, including loss of the fatty hilum, the presence of posterior acoustic shadowing or enhancement, and the Solbiati index. Other key US information concern the shape, border, architecture, echogenicity, echotexture, focal infiltration, bulky mass, blood vessel density, vascular pattern, resistance index, and elastography of the 
LN $[16,17]$. Additional information on the $\mathrm{LN}$ vascular pattern can be provided by the power Doppler; this pattern differs in normal, inflammatory, and neoplastic LN, and may be perinodal, intranodal, diffuse, or localized (Table 2). US provides useful information on the approach to the target LN, avoiding adjacent vascular structures and the LN hilum. In the case of multiple enlarged LN, US helps in selecting the most significant or the most approachable LN to be targeted, where additional passes can be performed.

The serologic evaluation of a patient with LAP should consider the history and the clinical evaluation of the LN and is usually requested after 2 weeks of persistent LAP. Basic laboratory tests as part of the workup include a full or complete blood count (FBC or $\mathrm{CBC}$ ) and the review of the peripheral blood smear and chemical serum analytes, such as lactate dehydrogenase, beta-2-microglobulin, creatinine, and serum immunoglobulins. The evaluation of hepatic and renal function and urine analysis are useful in identifying underlying systemic disorders that may be associated with LAP. High serum levels of lactate dehydrogenase suggest neoplasia or lymphoma.

Titers for specific infections or antibodies may also be useful. Heterophile antibody tests, FBC, and peripheral blood smear review (atypical lymphocytes) are indicated for suspected infectious mononucleosis. Cytomegalovirus (CMV) infection can be identified by CMV IgM and IgG antibody titers, CMV polymerase chain reaction (PCR), and CMV antigenemia test. Toxoplasma gondii and Bartonella henselae infections can be identified by elevated titers of IgM and IgG antibodies as well as PCR for specific DNA sequences. The Sabin-Feldman test is most used for suspected toxoplasmosis. The standard testing for Lyme disease is 2-tiered serology: the first-tier EIA quantifies potential antibodies against Borrelia burgdorferi; if this test is positive or equivocal, second-tier immunoblotting can detect antibodies against $B$. burgdorferi surface proteins. In suspected cases of lymphogranuloma venereum, anti-chlamydia IgA and a complement fixation test are used. Serum VDRL (venereal disease research laboratory test), rapid plasma reagin, fluorescence treponemal antibody absorption, and microhemagglutination assay are indicated for suspected Treponema pallidum infection. In patients with suspected human immunodeficiency virus (HIV) infection, HIV antibodies (ELISA), HIV viral RNA quantitative assay, rapid HIV test, and Western blot are used. Acid-fast bacilli stain, PCR, culture, and skin tuberculin test are used for suspected mycobacterial infection [18-20], and the Ziehl-Neelsen stain for Mycobacterium tuberculosis and Wade-Fite stain for
M. leprae. Serum latex agglutination and ELISA for fungal antigens may be used for cryptococcus infections [21]. Rheumatoid factor, other autoantibodies, pharyngeal swab, and Mantoux intradermal reaction are other tests that can be used in appropriate clinical situations.

\section{LN-FNAC Indications}

When the clinical and US presentation is less clear and serological data do not explain or do not match the clinical context, diagnostic imaging and/or pathological evaluation are required. Computed tomography (CT) with or without positron emission tomography and other noninvasive procedures are used to identify the nature of the LAP. However, these non-invasive procedures lead infrequently to a definitive diagnosis and, if LAP persists, pathological assessment with FNAC, core-needle biopsy (CNB), and/or surgical excision and histopathological evaluation are required. Criteria for LN-FNAC operators and preanalytical issues are provided in Table 3.

Traditionally, excisional biopsy of an enlarged LN has been the standard approach to establish a diagnosis, and histopathological examination has formed the basis for therapy and prognostic evaluation in patients with metastatic carcinomas and lymphomas. However, excisional biopsy is a demanding procedure for the patient, the physician, and the healthcare system in general. It usually requires hospitalization, a surgical procedure with at least local anesthetic and sedation, and has a greater risk of complications. CNB has been increasingly used to obtain material for histopathology but is a sampling technique with its own limitations and complication rate [22]. For the most frequent causes of LAP, such as benign reactive hyperplasia, specific infections or a metastasis from a known or unknown primary tumor, LN-FNAC is an accurate, quick, and cost-effective procedure, often making LN excisional biopsy an unnecessary and costly alternative. FNAC can determine whether a palpable or impalpable mass is actually an LN and distinguish a benign from a malignant entity, or a hematolymphoid from a non-hematolymphoid process. LN-FNAC can be the first-choice procedure for patients who are poor candidates for surgical biopsy or with abnormal LN in deep or inaccessible locations. However, without widely accepted guidelines on LN-FNAC technical procedures and diagnostic criteria, the use of FNAC and the value of FNAC diagnoses varies between countries and institutions.

The authors of this consensus agree that an LN-FNAC diagnosis made in conjunction with appropriate ancillary 
Table 3. LN-FNAC: operator, preanalytical procedures, ancillary techniques

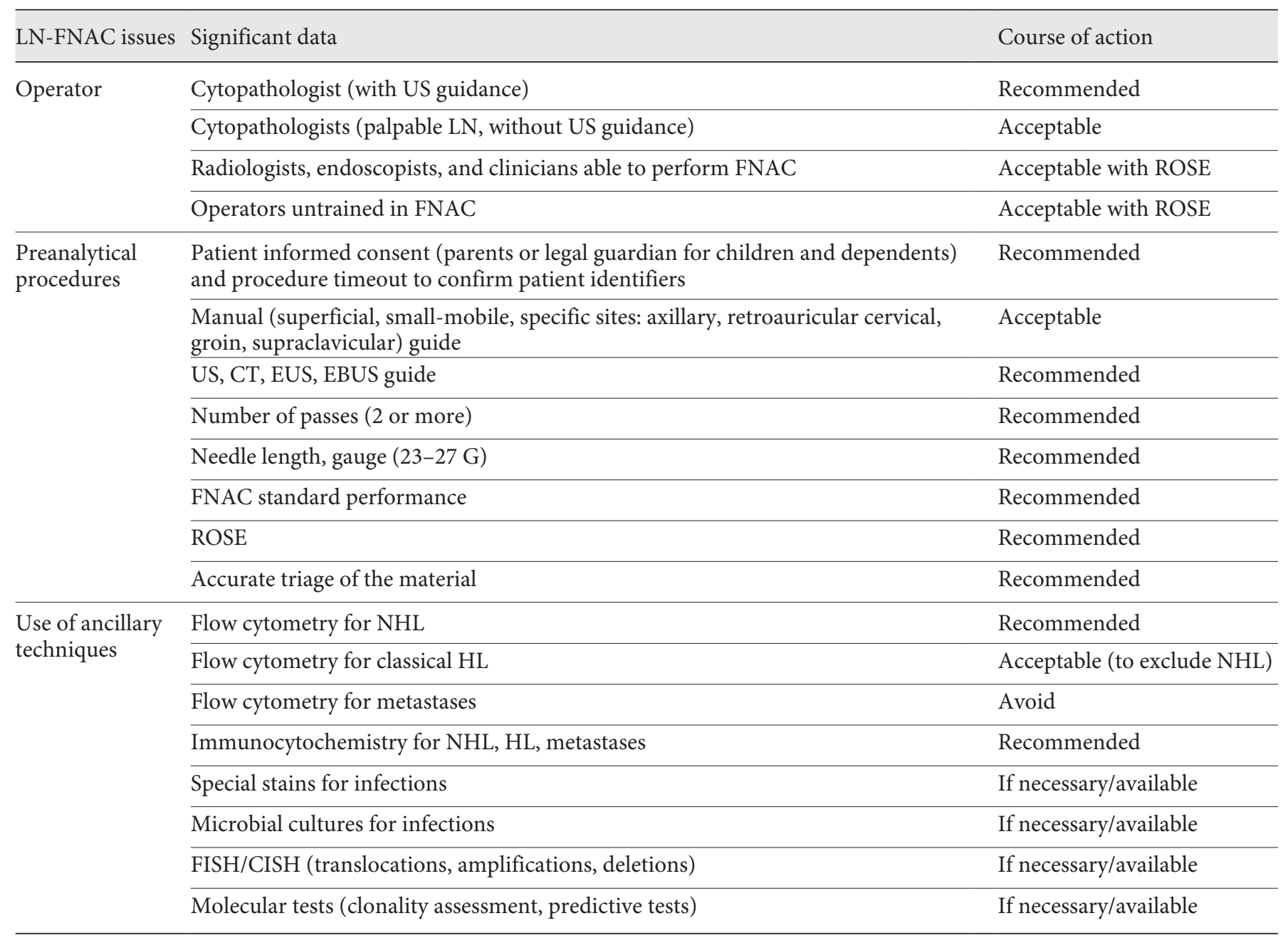

techniques, when necessary, and in a proper clinical context does not require histopathological confirmation in cases of benign reactive lymphoid hyperplasia, specific infections, recurrent lymphoproliferative disorders, and metastases. In these patients, a CNB may add value and be suggested if it can be performed safely but is not routinely required. If there is uncertainty regarding the FNAC diagnosis or there is discrepancy between the clinical, imaging, or serological findings and the FNAC diagnosis, CNB or excision biopsy is recommended.

Furthermore, histological confirmation of LN-FNAC findings is recommended for the primary diagnosis of Hodgkin lymphoma (HL) and non-HL (NHL), except for specific clinical situations or in certain anatomical locations in which biopsies or surgery are contraindicated or not possible. This recommendation, however, can be tailored to the type of lymphoma suspected. For instance, in a patient with chronic lymphocytic leukemia/small lymphocytic lymphoma, LN-FNAC with flow cytometry (FC) immunophenotyping is usually sufficient without histopathological confirmation. In certain specific clinical situations or in certain anatomical locations, CNB or excision biopsy are contraindicated or not possible, but histopathological examination may be required as part of some clinical treatment protocols.

LN-FNAC can be particularly useful in staging and follow up, including the response to treatment, in patients with known malignant processes. LN-FNAC can obtain tissue for immunophenotypic and molecular studies and obtain cellular and genetic material for storage. Furthermore, LN-FNAC can be used to determine eligibility for clinical trials and research protocols, since many patients with widespread metastatic disease have easily accessible LN that can be safely and repeatedly targeted with FNAC $[2-8,23]$. 
The performance of LN-FNAC involves a number of considerations, including clinical evaluation, US examination, the performance by palpation or US guidance, the making of direct smears, triaging the case for ancillary tests, and optimal management of the material and cytopathological assessment. All these steps are optimized if the procedure is performed by cytopathologists or by other well-trained physicians, including radiologists, endoscopists, or other clinicians, in the presence of a cytopathologist for rapid on-site evaluation (ROSE) and immediate triage of the diagnostic material (Table 1) [24, 25].

\section{Patient Informed Consent}

The informed consent of patients is required, based on the guidelines of the Internal Review Board or Ethics Committee of the involved institution. Consent should emphasize the importance of providing patients with adequate information about the LN-FNAC procedure, the accuracy of the LN-FNAC diagnosis and its limitations, enabling them to make informed decisions. Parents or legal guardians are responsible for the informed consent of pediatric or incompetent patients (Table 1).

\section{LN-FNAC Techniques and Procedural Considerations}

FNAC of both palpable and impalpable LN can be guided by US, CT, and transesophageal or transbronchial endoscopic US (EUS-EBUS) where available. For palpable, superficial, and bulky LN, and/or in specific anatomical sites, such as axillary LNs, the needle can be guided by palpation. US guidance for FNAC is recommended for palpable LN in other sites to improve the placement of the needle and accuracy of sampling but is not essential [26].

FNAC requires labelled glass slides, 23-, 25-, or 27-G needles of different lengths, preferably with a flanged tip, disinfectant, gauze, and band aid or simple adhesive dressing. Ten- or twenty-milliliter syringes attached to the needle provide a closed system and where necessary negative pressure for aspiration and can be used with a mechanical syringe holder. Alternatively, a non-aspiration technique using the needle-only technique is well suited to LN-FNAC. The needle-only technique is useful for cases requiring superior fine motor control (e.g., pediatric biopsies, small mobile LNs), for anxious patients fearful of the large syringe holder and syringe, or in LN that have increased vascularity to decrease peripheral blood dilution of the specimen.
LN-FNAC material should be expelled gently so that it can be divided into small drops to prepare multiple conventional smears or used for ancillary techniques. The number of prepared slides depends on the quantity of material, the diagnostic needs, and clinical situation. Expelling all the aspirated material on one single slide minimizes the ability to have material for additional testing and might also lead to thick suboptimal smearing. A specimen-splitting technique which divides the material for routine Romanowsky-type staining and alcohol-fixed $\mathrm{Pa}$ panicolaou staining and other special stains is recommended by some authors [27]. The smearing technique may be chosen based on the quality of the material: a hematologic technique (smearing with the edge of another slide) is used in the case of fluid material, whereas a direct smear (smearing between two slides or "pull-apart" smearing) is advisable in cases with bloody or dense material. Slide preparation should be rapid to prevent coagulation and drying artifact. The pressure exerted on the slides should be gentle, but firm and uniform in order to avoid mechanical trauma, provide a uniform thin smear, and to preserve the morphology of lymphoid cells that are fragile and easily crushed. Two conventional smears, one air dried for the Diff-Quik type stain and one immediately alcohol fixed for the Papanicolaou stain, are recommended in all cases. Hematoxylin and eosin can also be helpful in some cases.

Residual material in the needle and in some cases the syringe, and the material from additional passes is managed according to the clinical and imaging information, greatly assisted by the provisional ROSE. Multiple passes may be required to achieve sufficient tissue for ancillary studies, including cytospins, liquid-based cytology, cell blocks (CB), and additional smears for special stains according to their specific performance on the different supports in different pathological processes and according to their availability in different laboratories (Table 3) [28]. The preparation of a CB by various methods, including rapid fixation in formalin to be followed by centrifugation, is always recommended and may obviate the need for histopathological examination if a generous sample is available.

When LN-FNAC is not performed by cytopathologists or well-trained radiologists or endoscopists and no ROSE is available for triage, liquid-based cytology may be acceptable but air-dried stains cannot be used, pattern recognition of slides is reduced, cytomorphology is limited to alcohol-fixed Papanicolaou stains, and FC immunophenotyping cannot be performed. If it is not possible for a cytopathologist to perform ROSE, the opera- 
Table 4. LN-FNAC: first and second diagnostic levels and post-LN-FNAC management

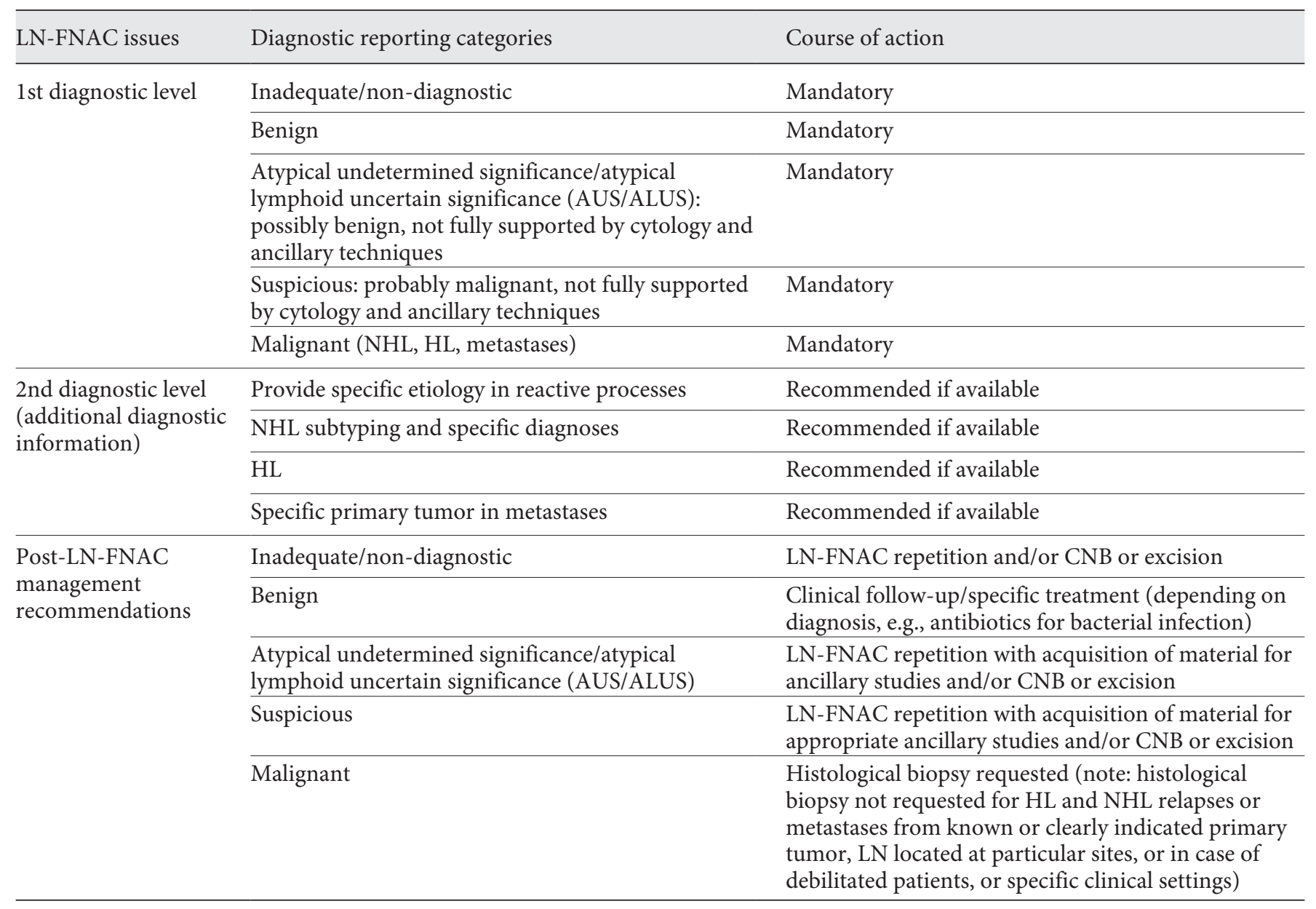

tor performing the FNAC should be provided a protocol for making appropriate direct smears, and rinse each needle and syringe in buffered saline or other appropriate medium suitable for either FC or CB preparation (Table 1).

Ancillary techniques including immunocytochemistry (ICC), FC, fluorescence or colorimetric in situ hybridization (FISH or CISH), and molecular procedures are required for an accurate LN-FNAC diagnosis in many patients, especially in cases of NHL (Table 3). Ancillary techniques are generally used to distinguish NHL from benign reactive lymphoid hyperplasia, to classify NHL, and to identify diagnostic cells in HL and metastases. FNAC material is often scant and the choice of a specific technique is aimed at the most effective use of the material, as suggested by several algorithms (Table 4) [29-42].

System for Reporting Lymph Node FNAC

\section{Proposed Diagnostic Reporting Categories for LN-FNAC: Recommendations and Indications}

A proposal for a diagnostic system for reporting $\mathrm{LN}$ FNAC has been developed by the above-reported panel of international cytopathologists. This system has two diagnostic levels; the first diagnostic level contains basic diagnostic information and includes the following five categories.

- Inadequate/Insufficient. This category includes cases that cannot be diagnosed due to scant cellularity, extensive necrosis, or technical limitations that cannot be overcome; repeat FNAC or CNB or excision biopsy should be requested based on the specific clinical context.

- Benign. This category includes cases with suppurative and granulomatous inflammation and specific infections, and other cases with a heterogeneous lymphoid 
population with small lymphocytes predominating, and often germinal centers with dendritic cells and tingible body macrophages. The lymphoid proliferations can be diagnosed as reactive with or without FC or ICC and referred for clinical follow-up when the FNAC findings agree with the clinical presentation and US features. When the clinical or US features are discrepant or suspicious, repeat LN-FNAC with immunophenotyping, preferably by $\mathrm{FC}$, is required.

- Atypical (Cells) Undetermined Significance/Atypical Lymphoid (Cells) of Uncertain Significance (ALUS/ AUS). This category includes cases with a heterogeneous lymphoid population where the features suggest a reactive process, but a follicular lymphoma cannot be excluded or where there is an excess of large cells (centroblasts or immunoblasts) or immature small lymphoid cells or cases where the atypical cells are not lymphoid cells. For these last cases, AUS should be used. Repeat FNAC, preferably with FC and cytogenetics, or CNB or excisional biopsy is required regardless of clinical and US findings.

- Suspicious. This category includes cases with small and/or medium-sized, monomorphic atypical lymphoid cells suspicious of lymphoma, but the cytomorphology alone is not sufficient and FC or ICC results are not available or do not demonstrate B-cell monoclonality; polymorphous lymphoid smears in which few Hodgkin- or Reed-Sternberg-like cells are detected and ICC is not performable or has not been diagnostic; large cell or Burkitt lymphomas scantly cellular in which ancillary techniques are not available; smears in which atypical cells suspicious for metastasis are detected, but are too scant to be diagnostic and there is no $\mathrm{CB}$ material available to perform ICC. Repeating FNAC to obtain a diagnostic $\mathrm{CB}$ may be one of the management options, or CNB or excisional biopsy is required.

- Malignant. This category includes small to mediumsized cells of NHL supported by evidence of clonality shown by FC or molecular studies showing clonal immunoglobulin (IGH or IGK) or T-cell receptor (TRG, $T R B)$ gene rearrangements and all the entities in which cytopathological features alone are sufficient to identify malignancy as large cell NHL. This category also includes HL in which there is an appropriate cellular background and diagnostic Hodgkin and Reed-Sternberg cells as well as metastatic neoplasms.

After categorization each case should have a specific diagnosis established, or if not possible, a preferred diagnosis should be made with a discussion of the possible differential diagnoses. For example, a benign categorization should be followed by a diagnostic statement that granulomatous inflammation is present, and acid-fast bacilli are seen on the Ziehl-Neelsen stain. Other examples include a large cell lymphoma present and the case is categorized as malignant and correlation with FC is required, or metastatic carcinoma is present, and the case is categorized as malignant.

The second diagnostic level, if achievable, provides additional information and identification of specific entities by utilizing ancillary testing. The goal of the second diagnostic level is to:

- identify specific benign entities, such as specific infections for example, using PCR, culture, and drug sensitivity results to confirm a mycobacterial infection or by ICC or ISH for EBV infection

- diagnose specific NHL entities as listed in the current WHO hematopathology classification using FC for Bcell monoclonality and other specific markers; for example, the diagnosis of mantle cell lymphoma is supported by CD5+ B-cell lineage, best shown by FC, combined with cyclin D1 and/or SOX11 positivity shown by ICC

- diagnose the site of origin of a primary tumor in LN metastases and any possible prognostic or treatment markers; for example, the estrogen and progesterone receptors and HER2 status in metastatic breast carcinoma

When the combination of the cytomorphology and ancillary testing findings allows the cytopathologist to achieve the second diagnostic level, corresponding findings should be reported in one final integrated cytopathology report with the diagnosed specific entity. The criteria for the first and second diagnostic levels and management recommendations for LN-FNAC are summarized in Table 5 [38, 41, 43-174].

\section{LN-FNAC Report}

The LN-FNAC report should be composed of different sections that summarize the entire procedure. The report should include: patient demographics, referring doctor, the target site, clinical and US features, a description of the LN-FNAC procedure (the needle gauge, guidancetype, number of passes, number of prepared smears, fixation and staining, and the management and allotment of material for ancillary tests). The report should provide one of the five first-level diagnostic categories followed by a clear cytomorphological description focusing on key cy- 
Table 5. 2017 WHO classification of mature lymphoid, histiocytic and dendritic neoplasms identifiable by LN-FNAC

Mature B-cell neoplasms [38, 43-50]

Chronic lymphocytic leukemia/small lymphocytic lymphoma [38, 43-51]

Monoclonal B-cell lymphocytosis, new entity

B-cell prolymphocytic leukemia

Splenic marginal zone lymphoma

Hairy cell leukemia [52-55]

Splenic B-cell lymphoma/leukemia, unclassifiable, provisional entity

Splenic diffuse red pulp small B-cell lymphoma, provisional entity

Hairy cell leukemia-variant, provisional entity

Lymphoplasmacytic lymphoma [38, 43-50]

Waldenström macroglobulinemia

Monoclonal gammopathy of undetermined significance (MGUS), immunoglobulin, new entity

$\mu$ heavy-chain disease, $\gamma$ heavy-chain disease, $a$ heavy-chain disease

MGUS, immunoglobulin G/A, provisional/new entity

Plasma cell myeloma [56]

Extraosseous plasmacytoma [56, 60-68]

Monoclonal immunoglobulin deposition diseases, new entity

Extranodal marginal zone lymphoma of mucosa-associated lymphoid tissue [69-72]

Nodal marginal zone lymphoma [38, 43-50, 73-75]

Pediatric nodal marginal zone lymphoma, provisional entity

Follicular lymphoma [38, 43-50, 76-78]

In situ follicular neoplasia

Duodenal-type follicular lymphoma, new entity

Pediatric-type follicular lymphoma, new entity

Large B-cell lymphoma with IRF4 rearrangement, provisional/new entity

Primary cutaneous follicle center lymphoma

Mantle cell lymphoma [38, 43-50, 79, 80]

In situ mantle cell neoplasia, new entity

Diffuse large B-cell lymphoma (DLBCL), NOS [38, 43-50, 81]

Germinal center B-cell type, new entity [81]

Activated B-cell type, new entity [81]

T-cell/histiocyte-rich large B-cell lymphoma [82]

Primary cutaneous DLBCL, leg type [83]

$\mathrm{EBV}+\mathrm{DLBCL}, \mathrm{NOS}$, new entity

$\mathrm{EBV}+$ mucocutaneous ulcer, provisional/new entity

DLBCL associated with chronic inflammation, new entity

Lymphomatoid granulomatosis $[84,85]$

Primary mediastinal (thymic) large B-cell lymphoma

Intravascular large B-cell lymphoma

ALK+ large B-cell lymphoma $[86,87]$

Plasmablastic lymphoma [88-91]

Primary effusion lymphoma [92-94]

HHV8+ DLBCL, NOS, provisional/new entity

Burkitt lymphoma [38, 43-50, 95-97]

Burkitt-like lymphoma with $11 \mathrm{q}$ aberration, provisional/new entity

High-grade B-cell lymphoma, with MYC and BCL2 and/or BCL6 rearrangements

High-grade B-cell lymphoma, NOS

B-cell lymphoma, unclassifiable, with features intermediate between DLBCL and classical Hodgkin lymphoma [102]

Mature T and NK neoplasms [99-104]

T-cell prolymphocytic leukemia

T-cell large granular lymphocytic leukemia

Chronic lymphoproliferative disorder of NK cells, provisional/new entity

Aggressive NK-cell leukemia

Systemic EBV+ T-cell lymphoma of childhood - new entity

Hydroa vacciniforme-like lymphoproliferative disorder, new entity

Adult T-cell leukemia/lymphoma [99-104]

Extranodal NK-/T-cell lymphoma, nasal type [99-104] 
Enteropathy-associated T-cell lymphoma [105]

Monomorphic epitheliotropic intestinal T-cell lymphoma

Indolent T-cell lymphoproliferative disorder of the gastrointestinal tract, provisional/new entity

Hepatosplenic T-cell lymphoma [106]

Subcutaneous panniculitis-like T-cell lymphoma $[107,108]$

Mycosis fungoides, Sézary syndrome $[109,110]$

Primary cutaneous CD30+ T-cell lymphoproliferative disorders

Lymphomatoid papulosis

Primary cutaneous anaplastic large cell lymphoma

Primary cutaneous $\gamma \delta$ T-cell lymphoma

Primary cutaneous CD8+ aggressive epidermotropic cytotoxic T cell

lymphoma provisional/new entity

Primary cutaneous acral CD8+ T-cell lymphoma, provisional/new entity

Primary cutaneous CD4+ small/medium T-cell lymphoproliferative disorder, provisional/new entity

Peripheral T-cell lymphoma, NOS [111-113]

Angioimmunoblastic T-cell lymphoma [114, 115]

Follicular T-cell lymphoma, provisional/new entity

Nodal peripheral T-cell lymphoma with TFH phenotype, provisional/new entity

Anaplastic large-cell lymphoma, ALK+ [116-129]

Anaplastic large-cell lymphoma, ALK- [116-129]

Breast implant-associated anaplastic large-cell lymphoma, provisional/new entity [130-138]

Hodgkin lymphoma [116, 139-152]

Nodular lymphocyte predominant Hodgkin lymphoma [139, 140]

Classical Hodgkin lymphoma [116, 141-149]

Nodular sclerosis classical Hodgkin lymphoma [150-152]

Lymphocyte-rich classical Hodgkin lymphoma

Mixed cellularity classical Hodgkin lymphoma

Lymphocyte-depleted classical Hodgkin lymphoma

Posttransplant lymphoproliferative disorders (PTLD) $[153,154]$

Plasmacytic hyperplasia PTLD

Infectious mononucleosis PTLD

Florid follicular hyperplasia PTLD, new entity

Polymorphic PTLD

Monomorphic PTLD (B- and T-/NK-cell types)

Classical Hodgkin lymphoma PTLD

Histiocytic and dendritic cell neoplasms

Histiocytic sarcoma [155-157]

Langerhans cell histiocytosis [148, 158-164]

Langerhans cell sarcoma $[165,166]$

Indeterminate dendritic cell tumor

Interdigitating dendritic cell sarcoma [166-169]

Follicular dendritic cell sarcoma [170-173]

Disseminated juvenile xanthogranuloma

Adapted from Swerdlow et al. [1]. Entities identifiable by FNAC are reported in bold with corresponding references.

topathological components that are diagnostic for specific lesions, if present, the ancillary tests that are underway, if any, or required to enhance the diagnosis, and a summary conclusion. When cytomorphological features correlated with subsequent ancillary test results are diagnostic of a specific pathological entity, including specific types of reactive LAP and lymphadenitis, specific infec- tion, NHL, HL, and metastases, a final report and conclusion can be issued as a second diagnostic level in one allencompassing report. This report may include prognostic and therapy-related predictive markers, for example, the EGFR status for an LN metastatic lung adenocarcinoma. The ancillary test results should be presented in the final report even if they are non-contributory and do not 
Table 6. LN-FNAC: report

\begin{tabular}{|c|c|c|}
\hline LN-FNAC issues & Procedures & Course of action \\
\hline \multirow{8}{*}{$\begin{array}{l}\text { LN-FNAC report } \\
\text { elements }\end{array}$} & Clinical data, site, imaging (US/CT) features & Recommended \\
\hline & $\begin{array}{l}\text { Procedure description: G-needle, guide, number of passes, ROSE, method, sample type(s), } \\
\text { processing, staining }\end{array}$ & Suggested \\
\hline & Basic diagnostic class (L1-L5) & Recommended \\
\hline & Microscopic description, ancillary technique/s used & Suggested \\
\hline & Secondary diagnosis or specific subtyping (if any) & Suggested \\
\hline & $\begin{array}{l}\text { Sample suitable (or not) for further studies (ICC, molecular) for predictive markers } \\
\text { (possibly \% content of the tumor) }\end{array}$ & Recommended \\
\hline & $\begin{array}{l}\text { Recommendations (follow-up for reactive, repetition-biopsy for undetermined/suspicious, } \\
\text { biopsy for first diagnosis HL-NHL, and undetermined metastases) }\end{array}$ & Suggested \\
\hline & Notes & If necessary \\
\hline
\end{tabular}

advance the cytomorphological diagnosis. Further recommendations based on the final report also can be made for management options. This information is summarized in Table 6.

\section{Conclusion}

The authors believe that the introduction of this standardized system for reporting for LN-FNAC may improve the quality of the procedure, the handling of material for diagnostic ancillary testing, and the understanding of the report and communication between the cytopathologist and the clinician, thereby improving patient care. This system may lead to a greater acceptance and utilization of LN-FNAC as a valuable, minimally invasive diagnostic method by all clinical disciplines, and will enable, in analogy to the Bethesda System for Reporting Thyroid FNAB Cytopathology [174], a better interdisciplinary understanding of the results of this procedure.

\section{Statement of Ethics}

This study has been performed in accordance with the ethical standards as laid down in the 1964 Declaration of Helsinki and its later amendments.

\section{Disclosure Statement}

The authors have no conflicts of interest to declare.

\section{Funding Sources}

The authors have no funding to report.

\section{Author Contributions}

All authors have equally contributed to the conceiving and design of the study, and analysis of data. I.C. and P.Z. wrote the manuscript.

\section{References}

1 Swerdlow S, Campo E, Harris NL, et al. WHO classification of tumours of haematopoietic and lymphoid tissues. revised 4th ed. Lyon: IARC; 2017.

2 Skoog L, Tani E, editors. Historical aspects. In: FNA cytology in the diagnosis of lymphoma. Monographs in Clinical Cytology, vol 18 Basel: Karger, 2009. pp 1-4.
3 Cibas ES, Ducatman BS. Lymph nodes. In Cytology: diagnostic principles and clinical correlates. 4th ed. Amsterdam: Elsevier Saunders; 2014.

4 Sheaff MT, Singh N. Lymph nodes. In: Cytopathology. Cham: Springer Ed; 2013. pp. 179207.
5 Caraway NP, Katz RL. Lymph nodes. Koss' diagnostic cytology and its histopathologic bases. Philadelphia: Lippincott Williams \& Wilkins; 2006. pp. 1186-228.

6 Young NA, Al-Saleem T. Lymph nodes: cytomorphology and flow cytometry. Comprehensive cytopathology. Amsterdam: Elsevier Saunders; 2008. pp. 671-711. 
7 Zeppa P, Cozzolino I. Fine-needle cytology: technical procedures and ancillary techniques. Monogr Clin Cytol. 2018;23:4-13.

8 Craig FE, Foon KA. Flow cytometric immunophenotyping for hematologic neoplasms. Blood. 2008 Apr;111(8):3941-67.

9 Hehn ST, Grogan TM, Miller TP. Utility of fine-needle aspiration as a diagnostic technique in lymphoma. J Clin Oncol. 2004 Aug; 22(15):3046-52.

10 Katz RL. Modern approach to lymphoma diagnosis by fine-needle aspiration: restoring respect to a valuable procedure. Cancer. 2005 Dec;105(6):429-31.

11 Zeppa P. Haematocytopathology: why? Cytopathology. 2012 Apr;23(2):73-5.

12 Monaco SE, Khalbuss WE, Pantanowitz L. Benign non-infectious causes of lymphadenopathy: a review of cytomorphology and differential diagnosis. Diagn Cytopathol. 2012; 40(10):925-38.

13 Richner S, Laifer G. Peripheral lymphadenopathy in immunocompetent Adults. Swiss Med Wkly. 2010;140:98-104

14 Bazemore AW, Smucker DR. Lymphadenopathy and malignancy. Am Fam Physician. 2002 Dec;66(11):2103-10.

15 Habermann TM, Steensma DP. Lymphadenopathy. Mayo Clin Proc. 2000 Jul;75(7):72332.

16 Cui XW, Hocke M, Jenssen C, Ignee A, Klein S, Schreiber-Dietrich D, et al. Conventional ultrasound for lymph node evaluation, update 2013. Z Gastroenterol. 2014 Feb;52(2): $212-21$.

17 Cui XW, Jenssen C, Saftoiu A, Ignee A, Dietrich CF. New ultrasound techniques for lymph node evaluation. World J Gastroenterol. 2013 Aug;19(30):4850-60.

18 Rajwanshi A, Bhambhani S, Das DK. Fineneedle aspiration cytology diagnosis of tuberculosis. Diagn Cytopathol. 1987 Mar;3(1): 13-6.

19 Radhika S, Gupta SK, Chakrabarti A, Rajwanshi A, Joshi K. Role of culture for mycobacteria in fine-needle aspiration diagnosis of tuberculous lymphadenitis. Diagn Cytopathol. 1989;5(3):260-2.

20 Nalini G, Kusum S, Barwad A, Gurpreet S, Arvind $\mathrm{R}$. Role of polymerase chain reaction in breast tuberculosis. Breast Dis. 2015;35(2): $129-32$.

21 BMJ Best practice. Assessment of Lymphadenopathy. http://bestpractice.bmj.com/bestpractice/monograph/838/diagnosis/differential-diagnosis.html

22 Groneck L, Quaas A, Hallek M, Zander T, Weihrauch MR. Ultrasound-guided core needle biopsies for workup of lymphadenopathy and lymphoma. Eur J Haematol. 2016 Oct; 97(4):379-86
23 Medeiros L, O’Malley D, Caraway N, Vega F, Elenitoba-Johnson K, Lim M. Needle core biopsy and fine-needle aspiration for the diagnosis of lymphoproliferative disorders. Tumors of the lymph nodes and spleen. AFIP Atlas of Tumor Pathology, 4th Series, Fascicle 25. Washington: American Registry of Pathology; 2017. pp. 43-64.

24 Manzo JL, Cuda J, Pantanowitz L, Xing J, Yu J, Beasley HS, et al. Clinical trial cytology: use of on-site evaluation of small biopsy and FNA samples for clinical trials and biomarker research studies. Cancer Cytopathol. 2018 Jul; 126(7).

25 Grohs HK. The interventional cytopathologist. A new clinician/pathologist hybrid. Am J Clin Pathol. 1988 Sep;90(3):351-4.

26 Bardales RH. The interventional cytopathologist. The invasive cytopathologist. Berlin: Springer; 2014. pp. 13-32.

27 Field AS, Geddie WR. Lymph node and spleen cytohistology. Cambridge: Cambridge University Press; 2014.

28 Barroca H, Bode-Lesniewska B, Cozzolino I, Zeppa P. Management of cytologic material, preanalytic procedures and biobanking in lymph node cytopathology. Cytopathology. 2019 Jan;30(1):17-30.

29 Schmitt FC. Molecular cytopathology and flow cytometry: pre-analytical procedures matter. Cytopathology. 2011 Dec;22(6):355-

30 Schmitt F, Barroca H. Role of ancillary studies in fine-needle aspiration from selected tumors. Cancer Cytopathol. 2012 Jun;120(3): 145-60.

31 Schmitt F, Cochand-Priollet B, Toetsch M, Davidson B, Bondi A, Vielh P. Immunocytochemistry in Europe: results of the European federation of cytology societies (efcs) inquiry. Cytopathology. 2011 Aug;22(4):238-42.

32 Pinheiro C, Roque R, Adriano A, Mendes P, Praça M, Reis I, et al. Optimization of immunocytochemistry in cytology: comparison of two protocols for fixation and preservation on cytospin and smear preparations. Cytopathology. $2015 \mathrm{Feb} ; 26(1): 38-43$.

33 Cozzolino I, Vigliar E, Sosa Fernandez LV, Selleri C, Pepe S, Vitale M, Triggiani M, Zeppa P. Non lymphomatous clonal B-Cell populations in enlarged lymph nodes in acquired immunodeficiency syndrome. Infez Med. 2012;20 Suppl 2:35-42.

34 Skoog L, Tani E. Immunocytochemistry: an indispensable technique in routine cytology. Cytopathology. 2011 Aug;22(4):215-29.

35 Zeppa P, Marino G, Troncone G, Fulciniti F, De Renzo A, Picardi M, et al. Fine-needle cytology and flow cytometry immunophenotyping and subclassification of non-Hodgkin lymphoma: a critical review of 307 cases with technical suggestions. Cancer. 2004 Feb; 102(1):55-65

36 Jin M, Wakely PE Jr. Lymph node cytopathology: essential ancillary studies as applied to lymphoproliferative neoplasms. Cancer $\mathrm{Cy}$ topathol. 2018 Aug;126(S8 Suppl 8):615-26.
37 Wakely PE Jr. Fine-needle aspiration cytopathology in diagnosis and classification of malignant lymphoma: accurate and reliable? Diagn Cytopathol. 2000 Feb;22(2):120-5.

38 Dey P. Role of ancillary techniques in diagnosing and subclassifying non-Hodgkin's lymphomas on fine needle aspiration cytology. Cytopathology. 2006 Oct;17(5):275-87.

39 Robins DB, Katz RL, Swan F Jr, Atkinson EN, Ordonez NG, Huh YO. Immunotyping of lymphoma by fine-needle aspiration. A comparative study of cytospin preparations and flow cytometry. Am J Clin Pathol. 1994 May; 101(5):569-76.

40 Zardawi IM, Jain S, Bennett G. Flow-cytometric algorithm on fine-needle aspirates for the clinical workup of patients with lymphadenopathy. Diagn Cytopathol. 1998 Oct;19(4): 274-8.

41 Bangerter M, Brudler O, Heinrich B, Griesshamnuer M. Fine needle aspiration cytology and flow cytometry in the diagnosis and subclassification of non-Hodgkin's lymphoma based on the World Health Organization classification. Acta Cytol. 2007 May-Jun; 51(3):390-8.

42 Mathiot C, Decaudin D, Klijanienko J, Couturier J, Salomon A, Dumont J, et al. Fine-needle aspiration cytology combined with flow cytometry immunophenotyping is a rapid and accurate approach for the evaluation of suspicious superficial lymphoid lesions. Diagn Cytopathol. 2006 Jul;34(7):472-8.

43 Stewart CJ, Duncan JA, Farquharson M, Richmond J. Fine needle aspiration cytology diagnosis of malignant lymphoma and reactive lymphoid hyperplasia. J Clin Pathol. 1998 Mar;51(3):197-203.

44 Wakely PE Jr. Fine needle aspiration cytopathology of malignant lymphoma. Clin Lab Med. 1998 Sep;18(3):541-59.

45 Henrique RM, Sousa ME, Godinho MI, Costa I, Barbosa IL, Lopes CA. Immunophenotyping by flow cytometry of fine needle aspirates in the diagnosis of lymphoproliferative disorders: A retrospective study. J Clin Lab Anal, 1999;13(5):224-8.

46 Meda BA, Buss DH, Woodruff RD, Cappellari JO, Rainer RO, Powell BL, et al. Diagnosis and subclassification of primary and recurrent lymphoma. The usefulness and limitations of combined fine-needle aspiration cytomorphology and flow cytometry. Am J Clin Pathol. 2000 May;113(5):688-99.

47 Mayall F, Dray M, Stanley D, Harrison B, Allen R. Immunoflow cytometry and cell block immunohistochemistry in the FNA diagnosis of lymphoma: a review of 73 consecutive cases. J Clin Pathol. 2000 Jun;53(6):451-7.

48 Dong HY, Harris NL, Preffer FI, Pitman MB. Fine-needle aspiration biopsy in the diagnosis and classification of primary and recurrent lymphoma: a retrospective analysis of the utility of cytomorphology and flow cytometry. Mod Pathol. 2001 May;14(5):472-81. 
49 Barrena S, Almeida J, Del Carmen GarcíaMacias M, López A, Rasillo A, Sayagués JM, et al. Flow cytometry immunophenotyping of fine-needle aspiration specimens: utility in the diagnosis and classification of non-Hodgkin lymphomas. Histopathology. 2011 May; 58(6):906-18.

50 Schmid S, Tinguely M, Cione P, Moch H, Bode B. Flow cytometry as an accurate tool to complement fine needle aspiration cytology in the diagnosis of low-grade malignant lymphomas. Cytopathology. 2011 Dec;22(6): 397-406.

51 Kastenbaum HA, Khalbuss WE, Felgar RE, Stoller R, Monaco SE. The spectrum of coincident entities with small lymphocytic lymphoma/chronic lymphocytic leukemia (SLL/ CLL) diagnosed by cytology. Cytojournal. 2010 Oct;7:20.

52 Kaw YT, Artymyshyn RL, Schichman SA, Salhany KE. Recurrent hairy cell leukemia presenting as a large mesenteric mass diagnosed by fine needle aspiration cytology. A case report. Acta Cytol. 1994 Mar-Apr;38(2):26770.

53 Pinto RG, Rocha PD, Vernekar JA. Fine needle aspiration of the spleen in hairy cell leukemia. A case report. Acta Cytol. 1995 Jul-Aug; 39(4):777-80.

54 Al-Za'abi AM, Boerner SL, Geddie W. Hairy cell leukemia presenting as a discrete liver mass: diagnosis by fine needle aspiration biopsy. Diagn Cytopathol. 2008 Feb;36(2):12832.

55 Subhawong AP, Subhawong TK, Ali SZ. Hairy cell leukemia presenting as a peripancreatic mass: cytomorphology and radiographic correlates. Acta Cytol. 2012;56(4): 463-6.

56 Handa U, Chhabra S, Mohan H. Plasma cell tumours: cytomorphological features in a series of 12 cases diagnosed on fine needle aspiration cytology. Cytopathology. 2010 Jun; 21(3):186-90.

57 Pattanayak L, Samantaray S, Rout N. Solitary plasmacytoma of the rib: a rare cytological detection. Indian J Cancer. 2010 Oct-Dec;47(4): 485-6.

58 Gill MK, Makkar M, Bains SP. Solitary plasmacytoma of skull: a rare cytological diagnosis. J Clin Diagn Res. 2013 Aug;7(8):1702-3.

59 Saksena A, Mahajan N, Agarwal S, Jain S. Solitary bone plasmacytoma: an interesting case report with unusual clinico-cytological features. J Cytol. 2014 Jul;31(3):158-60.

60 Goel G, Rai S, Naik R, Gupta A, Baliga P, Sinha R. Cytodiagnosis of extramedullary plasmacytomas. Acta Cytol. 2010 May-Jun; 54(3):255-8.

61 Das DK, Gupta SK, Sehgal S. Extramedullary plasma cell tumors: diagnosis by fine-needle aspiration cytology. Diagn Cytopathol. 1986 Sep;2(3):248-51.

62 Powers CN, Wakely PE Jr, Silverman JF, Kornstein MJ, Frable WJ. Fine needle aspiration biopsy of extramedullary plasma cell tumors. Mod Pathol. 1990 Nov;3(6):648-53.
63 Pai RR, Raghuveer CV. Extramedullary plasmacytoma diagnosed by fine needle aspiration cytology. A report of four cases. Acta Cytol. 1996 Sep-Oct;40(5):963-6.

64 Kumar PV, Owji SM, Talei AR, Malekhusseini SA. Extramedullary plasmacytoma. Fine needle aspiration findings. Acta Cytol. 1997 Mar-Apr;41(2):364-8.

65 Bangerter M, Hildebrand A, Waidmann O, Griesshammer M. Fine needle aspiration cytology in extramedullary plasmacytoma. Acta Cytol. 2000 May-Jun;44(3):287-91.

66 Mukunyadzi P, Bardales RH, Wilson CS, Sawyer JR, Stanley MW. Soft tissue masses in patients with multiple myeloma: a fine-needle aspiration study of 30 cases with flow cytometry and clinical correlation. Cancer. 2001 Aug;93(4):257-62.

67 Sarin H, Manucha V, Verma K. Extramedullary plasmacytoma, a report of five cases diagnosed by FNAC. Cytopathology. 2009 Oct; 20(5):328-31.

68 Lee CH, Jung YY, Chung YR, Ryu HS. Liquidbased cytologic findings of solitary extramedullary plasmacytoma in thyroid: a case report identified with fine-needle aspiration cytology. Diagn Cytopathol. 2014 Nov;42(11):9649.

69 Kaba S, Tokoro Y, Washiya K, Tokairin T, Ono I, Tsuchida S, et al. Cytology of pulmonary marginal zone B-cell lymphoma of MALT type: lessons learned for intra-operative diagnosis. Cytopathology. 2011 Oct; 22(5):346-9.

70 Ogura T, Tajika M, Hijioka S, et al, al. First report of a mucosa-associated lymphoid tissue (MALT) lymphoma of the esophagus diagnosed by endoscopic ultrasound-guided fine-needle aspiration (EUS-FNA). Endoscopy. 2012;44(S 02):E167-8.

71 Ko HM, Geddie WR, Boerner SL, Rogalla P, da Cunha Santos G. Cytomorphological and clinicopathological spectrum of pulmonary marginal zone lymphoma: the utility of immunophenotyping, PCR and FISH studies. Cytopathology. 2014 Aug;25(4):250-8.

72 Vigliar E, Caleo A, Vitale M, Di Crescenzo V, Garzi A, Zeppa P. Early cytological diagnosis of extranodal stage I, primary thyroid NonHodgkin lymphoma in elderly patients. Report of two cases and review of the literature. BMC Surg. 2013;13(suppl 2):S49.

73 Matsushima AY, Hamele-Bena D, Osborne BM. Fine-needle aspiration biopsy findings in marginal zone B cell lymphoma. Diagn Cytopathol. 1999 Apr;20(4):190-8.

74 Murphy BA, Meda BA, Buss DH, Geisinger KR. Marginal zone and mantle cell lymphomas: assessment of cytomorphology in subtyping small B-cell lymphomas. Diagn Cytopathol. 2003 Mar;28(3):126-30.

75 Crapanzano JP, Lin O. Cytologic findings of marginal zone lymphoma. Cancer. 2003 Oct; 99(5):301-9.
76 Gong Y, Caraway N, Gu J, Zaidi T, Fernandez $\mathrm{R}$, Sun X, et al. Evaluation of interphase fluorescence in situ hybridization for the $t(14 ; 18)$ (q32; $\mathrm{q} 21)$ translocation in the diagnosis of follicular lymphoma on fine-needle aspirates. Cancer. 2003;99(6):385-93.

77 Richmond J, Bryant R, Trotman W, Beatty B, Lunde J. FISH detection of $t(14 ; 18)$ in follicular lymphoma on Papanicolaou-stained archival cytology slides. Cancer. 2006 Jun; 108(3):198-204.

78 Kishimoto K, Kitamura T, Fujita K, Tate G, Mitsuya T. Cytologic differential diagnosis of follicular lymphoma grades 1 and 2 from reactive follicular hyperplasia: cytologic features of fine-needle aspiration smears with Pap stain and fluorescence in situ hybridization analysis to detect $\mathrm{t}(14 ; 18)$ (q32;q21) chromosomal translocation. Diagn Cytopathol. 2006 Jan;34(1):11-7.

79 Bentz JS, Rowe LR, Anderson SR, Gupta PK, McGrath CM. Rapid detection of the $t(11 ; 14)$ translocation in mantle cell lymphoma by interphase fluorescence in situ hybridization on archival cytopathologic material. Cancer. 2004 Apr;102(2):124-31.

80 Zhang YH, Liu J, Dawlett M, Guo M, Sun X, Gong Y. The role of SOX11 immunostaining in confirming the diagnosis of mantle cell lymphoma on fine-needle aspiration samples. Cancer Cytopathol. 2014 Dec;122(12):892-7.

81 Cozzolino I, Varone V, Picardi M, Baldi C, Memoli D, Ciancia G, et al. CD10, BCL6, and MUM1 expression in diffuse large B-cell lymphoma on FNA samples. Cancer Cytopathol. 2016 Feb;124(2):135-43.

82 Tong TR, Lee KC, Chow TC, Chan OW, Lam WW, Lung R. T-cell/histiocyte-rich diffuse large B-cell lymphoma. Report of a case diagnosed by fine needle aspiration biopsy with immunohistochemical and molecular pathologic correlation. Acta Cytol. 2002 Sep-Oct; 46(5):893-8.

83 Khatib Y, Dande M, Patel RD, Makhija M. Primary cutaneous large B-cell lymphoma of scalp: case report of a rare variant. Indian J Pathol Microbiol. 2017 Apr-Jun;60(2):26871.

84 Williams WL, Clark DA, Saiers JH. Fine needle aspiration diagnosis of lymphomatoid granulomatosis. A case report. Acta Cytol. 1992 Jan-Feb;36(1):91-4.

85 Vargas J, Arguelles M, Nevado M, de la Serna J, de Agustín P. Fine needle aspiration biopsy of a cutaneous relapse of lymphomatoid granulomatosis. A case report. Acta Cytol. 1993 Mar-Apr;37(2):205-8.

86 Sakr H, Cruise M, Chahal P, Cotta C, Cook J, Chalikonda S, et al. Anaplastic lymphoma kinase positive large B-cell lymphoma: literature review and report of an endoscopic fine needle aspiration case with tigroid backgrounds mimicking seminoma. Diagn Cytopathol. 2017 Feb;45(2):148-55. 
87 Lin O, Koreishi A, Brandt SM, Arcila M, Teruya-Feldstein J. ALK+ large B-cell lymphoma: a rare variant of aggressive large B-cell lymphoma mimicking carcinoma on cytology specimens. Diagn Cytopathol. 2013 May; 41(5):404-7.

88 Lin F, Zhang K, Quiery AT Jr, Prichard J, Schuerch C. Plasmablastic lymphoma of the cervical lymph nodes in a human immunodeficiency virus-negative patient: a case report and review of the literature. Arch Pathol Lab Med. 2004 May;128(5):581-4.

89 Lin O, Gerhard R, Zerbini MC, Teruya-Feldstein J. Cytologic features of plasmablastic lymphoma. Cancer. 2005 Jun;105(3):139-44.

90 Wang J, Hernandez OJ, Şen F. Plasmablastic lymphoma involving breast: a case diagnosed by fine-needle aspiration and core needle biopsy. Diagn Cytopathol. 2008 Apr;36(4):25761.

91 Bibas M, Baiocchini A. HIV-associated plasmablastic lymphoma diagnosed by fine-needle aspiration cytology. Korean J Hematol. 2011 Dec;46(4):214.

92 Galán J, Martin I, Carmona I, Rodriguez-Barbero JM, Cuadrado E, García-Alonso L, et al. The utility of multiparametric flow cytometry in the detection of primary effusion lymphoma (PEL). Cytometry B Clin Cytom. 2019 Sep;96(5):375-8.

93 Bode-Lesniewska B. Flow cytometry and effusions in lymphoproliferative processes and other hematologic neoplasias. Acta Cytol. 2016;60(4):354-64.

94 Tong LC, Ko HM, Saieg MA, Boerner S, Geddie WR, da Cunha Santos G. Subclassification of lymphoproliferative disorders in serous effusions: a 10-year experience. Cancer Cytopathol. 2013 May;121(5):261-70.

95 Oertel J, Oertel B, Lobeck H, Huhn D. Immunocytochemical analysis of lymph node aspirates in patients with human immunodeficiency virus infection. J Clin Pathol. 1990 Oct; 43(10):844-6.

96 Stelow EB, Policarpio-Nicolas ML, Sudduth KW, LeGallo RD. Burkitt lymphoma. Diagn Cytopathol. 2008 Mar;36(3):172-3.

97 Rymkiewicz G, Grygalewicz B, Chechlinska M, Blachnio K, Bystydzienski Z, Romejko-Jarosinska J, et al. A comprehensive flow-cytometry-based immunophenotypic characterization of Burkitt-like lymphoma with $11 \mathrm{q}$ aberration. Mod Pathol. 2018 May;31(5): 732-43.

98 Lynnhtun K, Varikatt W, Pathmanathan N. B cell lymphoma, unclassifiable, with features intermediate between diffuse large B cell lymphoma and classical hodgkin lymphoma: diagnosis by fine-needle aspiration cytology. Diagn Cytopathol. 2014 Aug;42(8):690-3.

99 Jiménez-Heffernan JA, González-Peramato P, Perna C, Alvarez-Ferreira J, López-Ferrer $\mathrm{P}$, Viguer JM. Fine-needle aspiration cytology of extranodal natural killer/T-cell lymphoma. Diagn Cytopathol. 2002 Dec;27(6):371-4.
100 Han Y, Kim KH, Choi IH. Cytological findings of NK/T-cell lymphoma in pericardial effusion: A case report with a review of the literature. Indian J Pathol Microbiol. 2019 Jul-Sep;62(3):473-6.

101 Das DK, Pathan SK, Joneja M, Al-Musawi FA, John B, Mirza KR. T-cell prolymphocytic leukemia (T-PLL) with overlapping cytomorphological features with T-CLL and T-ALL: a case initially diagnosed by fineneedle aspiration cytology and immunocytochemistry. Diagn Cytopathol. 2013 Apr; 41(4):360-5.

102 Dahmoush L, Hijazi Y, Barnes E, Stetler-Stevenson M, Abati A. Adult T-cell leukemia/ lymphoma: a cytopathologic, immunocytochemical, and flow cytometric study. Cancer. 2002 Apr;96(2):110-6.

103 Kaur K, Kakkar A, Bhardwaj N, Sakthivel P, Singh CA, Jain D, et al. Spectrum of cytomorphological features of extranodal NK/Tcell lymphoma, nasal type. Cytopathology. 2019 Jul;30(4):393-401.

104 Ng WK, Lee CY, Li AS, Cheung LK. Nodal presentation of nasal-type NK/T-cell lymphoma. Report of two cases with fine needle aspiration cytology findings. Acta Cytol. 2003 Nov-Dec;47(6):1063-8.

105 Schwock J, Hyjek EM, Torlakovic EE, Geddie WR. Enteropathy-associated intestinal T-cell lymphoma in cavitating mesenteric lymph node syndrome: fine-needle aspiration contributes to the diagnosis. Diagn Cytopathol. 2015 Feb;43(2):125-30.

106 Kumar R, Dey P, Das A, Sachdeva MS, Varma S. Hepatosplenic T-cell lymphoma is a distinct rare entity: diagnosis by fine-needle aspiration cytology. Diagn Cytopathol. 2011 Sep;39(9):677-80.

107 Kim HS, Joo M, Chang SH. FNA cytology of subcutaneous panniculitis-like T-cell lymphoma with granulomas: a diagnostic pitfall. Cytopathology. 2011 Feb;22(1):63-4.

108 Manosca F, Ariga R, Bengana C, Reddy VB, Loew J, Gattuso P. Fine-needle aspiration of subcutaneous panniculitis-like T-cell lymphoma. Diagn Cytopathol. 2004 Nov;31(5): 338-9.

109 Pai RK, Mullins FM, Kim YH, Kong CS. Cytologic evaluation of lymphadenopathy associated with mycosis fungoides and Sezary syndrome: role of immunophenotypic and molecular ancillary studies. Cancer. 2008 Oct;114(5):323-32.

110 Galindo LM, Garcia FU, Hanau CA, Lessin SR, Jhala N, Bigler RD, et al. Fine-needle aspiration biopsy in the evaluation of lymphadenopathy associated with cutaneous Tcell lymphoma (mycosis fungoides/Sézary syndrome). Am J Clin Pathol. 2000 Jun; 113(6):865-71.

111 Yao JL, Cangiarella JF, Cohen JM, Chhieng DC. Fine-needle aspiration biopsy of peripheral T-cell lymphomas. A cytologic and immunophenotypic study of 33 cases. Cancer. 2001 Apr;93(2):151-9.
112 Katz RL, Gritsman A, Cabanillas F, Fanning CV, Dekmezian R, Ordonez NG, et al. Fineneedle aspiration cytology of peripheral $\mathrm{T}$ cell lymphoma. A cytologic, immunologic, and cytometric study. Am J Clin Pathol. 1989 Feb;91(2):120-31.

113 Al Shanqeety O, Mourad WA. Diagnosis of peripheral $\mathrm{T}$-cell lymphoma by fine-needle aspiration biopsy: a cytomorphologic and immunophenotypic approach. Diagn Cytopathol. 2000 Dec;23(6):375-9.

114 Dey P, Radhika S, Das A. Fine-needle aspiration biopsy of angio-immunoblastic lymphadenopathy. Diagn Cytopathol. 1996 Dec; 15(5):412-4.

115 Ng WK, Ip P, Choy C, Collins RJ. Cytologic findings of angioimmunoblastic T-cell lymphoma: analysis of 16 fine-needle aspirates over 9-year period. Cancer. 2002 Jun;96(3): $166-73$.

116 Mourad WA, al Nazer M, Tulbah A. Cytomorphologic differentiation of Hodgkin's lymphoma and $\mathrm{Ki}-1+$ anaplastic large cell lymphoma in fine needle aspirates. Acta $\mathrm{Cy}$ tol. 2003 Sep-Oct;47(5):744-8.

117 Shin HJ, Thorson P, Gu J, Katz RL. Detection of a subset of CD30+ anaplastic large cell lymphoma by interphase fluorescence in situ hybridization. Diagn Cytopathol. 2003 Aug;29(2):61-6.

118 Ng WK, Ip P, Choy C, Collins RJ. Cytologic and immunocytochemical findings of anaplastic large cell lymphoma: analysis of ten fine-needle aspiration specimens over a 9-year period. Cancer. 2003 Feb;99(1):3343.

119 Rapkiewicz A, Wen H, Sen F, Das K. Cytomorphologic examination of anaplastic large cell lymphoma by fine-needle aspiration cytology. Cancer. 2007 Dec;111(6):499507.

120 Muzzafar T, Wei EX, Lin P, Medeiros LJ, Jorgensen JL. Flow cytometric immunophenotyping of anaplastic large cell lymphoma. Arch Pathol Lab Med. 2009 Jan;133(1):4956.

121 Das P, Iyer VK, Mathur SR, Ray R. Anaplastic large cell lymphoma: a critical evaluation of cytomorphological features in seven cases. Cytopathology. 2010 Aug;21(4):251-8.

122 Vij M, Dhir B, Verma R, Agrawal V, Agarwal V, Jaiswal S, et al. Cytomorphology of ALK+ anaplastic large cell lymphoma displaying spindle cells mimicking a sarcomatous tumor: report of a case. Diagn Cytopathol. 2011 Oct;39(10):775-9.

123 Agnihotri MA, Kothari KS, Naik LP, Patil S. Anaplastic large cell lymphoma: A great mimic on cytology. J Cytol. 2017 Jul-Sep; 34(3):165-7.

124 McCluggage WG, Anderson N, Herron B, Caughley L. Fine needle aspiration cytology, histology and immunohistochemistry of anaplastic large cell Ki-1-positive lymphoma. A report of three cases. Acta Cytol. 1996 JulAug;40(4):779-85. 
125 Bogdanic M, Ostojic Kolonic S, Kaic G, Kardum Paro MM, Lasan Trcic R, Kardum-Skelin I. Fine-needle aspiration cytology yield as a basis for morphological, molecular, and cytogenetic diagnosis in alk-positive anaplastic large cell lymphoma with atypical clinical presentation. Diagn Cytopathol. 2017 Jan;45(1):51-4.

126 Ramteke P, Chitragar S, Singh A, Mallick S, Mathur SR, Jain D, et al. Anaplastic lymphoma kinase immunocytochemistry in fine needle aspiration diagnosis of anaplastic large-cell lymphoma. J Cytol. 2018 Jan-Mar; 35(1):37-40.

127 Proca DM, De Renne L, Marsh WL Jr, Keyhani-Rofagha S. Anaplastic large cell lymphoma in a human immunodeficiency virus-positive patient with cytologic findings in bladder wash: a case report. Acta Cytol. 2008 Jan-Feb;52(1):83-6.

128 Hudacko R, Rapkiewicz A, Berman RS, Simsir A. ALK-negative anaplastic large cell lymphoma mimicking a soft tissue sarcoma. J Cytol. 2011 Oct;28(4):230-3.

129 Balachandran I, Walker JW Jr, Broman J. Fine needle aspiration cytology of ALK1(-), CD30+ anaplastic large cell lymphoma post renal transplantation: a case report and literature review. Diagn Cytopathol. 2010 Mar; 38(3):213-6

130 Chai SM, Kavangh S, Ooi SS, Sterrett GF, Cull G, Plunkett M, et al. Anaplastic largecell lymphoma associated with breast implants: a unique entity within the spectrum of peri-implant effusions. Diagn Cytopathol. 2014 Nov;42(11):929-38.

131 Talagas M, Uguen A, Charles-Petillon F, Conan-Charlet V, Marion V, Hu W, et al. Breast implant-associated anaplastic largecell lymphoma can be a diagnostic challenge for pathologists. Acta Cytol. 2014;58(1): 103-7.

$132 \mathrm{Wu}$ D, Allen CT, Fromm JR. Flow cytometry of ALK-negative anaplastic large cell lymphoma of breast implant-associated effusion and capsular tissue. Cytometry B Clin Cytom. 2015 Jan;88(1):58-63.

133 Granados R, Lumbreras EM, Delgado M, Aramburu JA, Tardío JC. Cytological diagnosis of bilateral breast implant-associated lymphoma of the alk-negative anaplastic large-cell type. Clinical implications of periimplant breast seroma cytological reporting. Diagn Cytopathol. 2016 Jul;44(7):623-7.

134 Di Napoli A, Pepe G, Giarnieri E, et al. Cytological diagnostic features of late breast implant seromas: from reactive to anaplastic large cell lymphoma. Tripodo C, editor. PLoS One. 2017 Jul;12(7):e0181097.

135 Ronchi A, Montella M, Argenzio V, Lucia A, De Renzo A, Alfano R, et al. Diagnosis of anaplastic large cell lymphoma on late periimplant breast seroma: management of cytological sample by an integrated approach. Cytopathology. 2018 Jun;29(3):294-9.
136 Di Napoli A. Achieving reliable diagnosis in late breast implant seromas. Plast Reconstr Surg. 2019 Mar;143(3S):15S-22S.

137 Barbé E, de Boer M, de Jong D. A practical cytological approach to the diagnosis of breast-implant associated anaplastic large cell lymphoma. Cytopathology. 2019 Jul; 30(4):363-9.

138 Subhawong AP, Ali SZ, Tatsas AD. Nodular lymphocyte-predominant Hodgkin lymphoma: cytopathologic correlates on fineneedle aspiration. Cancer Cytopathol. 2012 Aug;120(4):254-60.

139 Das DK, Sheikh ZA, Al-Shama'a MH, John B, Alawi AM, Junaid TA. A case of composite classical and nodular lymphocyte predominant Hodgkin lymphoma with progression to diffuse large B-cell non-Hodgkin lymphoma: diagnostic difficulty in fine-needle aspiration cytology. Diagn Cytopathol. 2017 Mar;45(3):262-6.

140 Das DK, Gupta SK. Fine needle aspiration cytodiagnosis of Hodgkin's disease and its subtypes. II. Subtyping by differential cell counts. Acta Cytol. 1990 May-Jun;34(3): 337-41.

141 Das DK, Gupta SK, Datta BN, Sharma SC. Fine needle aspiration cytodiagnosis of Hodgkin's disease and its subtypes. I. Scope and limitations. Acta Cytol. 1990 May-Jun; 34(3):329-36

142 Chhieng DC, Cangiarella JF, Symmans WF, Cohen JM. Fine-needle aspiration cytology of Hodgkin disease: a study of 89 cases with emphasis on false-negative cases. Cancer. 2001 Feb;93(1):52-9.

143 Mathur S, Verm K. Peripheral T-cell lymphoma not otherwise specified vs. Hodgkin's lymphoma on fine needle aspiration cytology. Acta Cytol. 2005 Jul-Aug;49(4): 373-7.

144 Zhang JR, Raza AS, Greaves TS, Cobb CJ. Fine-needle aspiration diagnosis of Hodgkin lymphoma using current WHO classification-re-evaluation of cases from 1999-2004 with new proposals. Diagn Cytopathol. 2006 Jun;34(6):397-402.

145 Zeppa P, Picardi M, Cozzolino I, Troncone G, Lucariello A, De Renzo A, et al. Fine-needle aspiration cytology in the follow-up of Hodgkin lymphoma. Diagn Cytopathol. 2008 Jul;36(7):467-72.

146 Das DK, Francis IM, Sharma PN, Sathar SA, John B, George SS, et al. Hodgkin's lymphoma: diagnostic difficulties in fine-needle aspiration cytology. Diagn Cytopathol. 2009 Aug;37(8):564-73.

147 Das DK, Sheikh ZA, Alansary TA, Amir T, Al-Rabiy FN, Junaid TA. A case of Langerhans' cell histiocytosis associated with Hodgkin's lymphoma: fine-needle aspiration cytologic and histopathological features. Diagn Cytopathol. 2016 Feb;44(2): $128-32$.
148 Florentine BD, Cohen AN. Nodular sclerosing classical Hodgkin lymphoma masquerading as acute suppurative-necrotizing lymphadenitis. Diagn Cytopathol. 2014 Mar;42(3):238-41.

149 Jogai S, Dey P, Al Jassar A, Amanguno HG, Adesina AO. Role of fine needle aspiration cytology in nodular sclerosis variant of Hodgkin's lymphoma. Acta Cytol. 2006 SepOct;50(5):507-12.

150 Kamal MM, Khude SR, Yadav SB, Raut WK Pangarkar MA. Syncytial variant of nodular sclerosing Hodgkin's disease: A diagnostic pitfall in fine-needle aspiration cytology. J Cytol. 2014 Apr;31(2):91-2.

151 Sharma S, Dey P, Mitra S, Rajwanshi A, Nijhawan R, Srinivasan R, et al. Nodular sclerosis classical Hodgkin lymphoma grade 2 A diagnostic challenge to the cytopathologists. Cancer Cytopathol. 2017 Feb;125(2): 104-13.

152 Gattuso P, Castelli MJ, Peng Y, Reddy VB. Posttransplant lymphoproliferative disorders: a fine-needle aspiration biopsy study. Diagn Cytopathol. 1997 May;16(5):392-5.

153 Ponder TB, Collins BT, Bee CS, Grosso LE, Dunphy $\mathrm{CH}$. Fine needle aspiration biopsy of a posttransplant lymphoproliferative disorder with pronounced plasmacytic differentiation presenting in the face. A case report. Acta Cytol. 2002 Mar-Apr;46(2):38994.

154 Miliauskas JR. Fine-needle aspiration cytology: true histiocytic lymphoma/histiocytic sarcoma. Diagn Cytopathol. 2003 Oct;29(4): 233-5.

155 Mallya V, Bansal A, Kapoor S. Fine needle aspiration of Histiocytic sarcoma. J Cytol. 2014 Oct-Dec;31(4):205-6.

156 Hung YP, Lovitch SB, Qian X. Histiocytic sarcoma: new insights into FNA cytomorphology and molecular characteristics. Cancer Cytopathol. 2017 Aug;125(8):604-14.

157 Lee JS, Lee MC, Park CS, Juhng SW. Fine needle aspiration cytology of Langerhans cell histiocytosis confined to lymph nodes. A case report. Acta Cytol. 1997 Nov-Dec; 41(6):1793-6.

158 Kakkar S, Kapila K, Verma K. Langerhans cell histiocytosis in lymph nodes. Cytomorphologic diagnosis and pitfalls. Acta Cytol. 2001 May-Jun;45(3):327-32.

159 Kumar PV, Mousavi A, Karimi M, Bedayat GR. Fine needle aspiration of Langerhans cell histiocytosis of the lymph nodes. A report of six cases. Acta Cytol. 2002 Jul-Aug, 46(4):753-6.

160 Lee LY, Kang CJ, Hsieh YY, Hsueh S. Diagnosis of nodal Langerhans cell histiocytosis by fine needle aspiration cytology. Chang Gung Med J. 2005 Oct;28(10):735-9.

161 Handa U, Kundu R, Punia RS, Mohan H. Langerhans cell histiocytosis in children diagnosed by fine-needle aspiration. J Cytol. 2015 Oct-Dec;32(4):244-7. 
162 Patne SC, Dwivedi S, Katiyar R, Gupta V, Gupta AK. Langerhans cell histiocytosis diagnosed by FNAC of lymph nodes. J Cancer Res Ther. 2015 Oct-Dec;11(4):1028.

163 Hang JF, Siddiqui MT, Ali SZ. Fine needle aspiration of langerhans cell histiocytosis: A cytopathologic study of 37 cases. Acta Cytol. 2017;61(2):96-102.

164 López-Ferrer P, Jiménez-Heffernan JA, Alves-Ferreira J, Vicandi B, Viguer JM. Fine needle aspiration cytology of langerhans cell sarcoma. Cytopathology. 2008;19(1):59-61.

165 Iwasaki K, Sakai Y, Mori M, Imamura Y. Liquid-based cytology in the diagnosis of Langerhans cell sarcoma: A case report. Diagn Cytopathol. 2018 Sep;46(9):782-5.

166 Yang GC, Besanceney CE, Tam W. Histiocytic sarcoma with interdigitating dendritic cell differentiation: a case report with fine needle aspiration cytology and review of literature. Diagn Cytopathol. 2010 May;38(5): 351-6.
167 Mehrotra S, Pan Z. Fine needle aspiration cytology of histiocytic sarcoma with dendritic cell differentiation: a case of transdifferentiation from low-grade follicular lymphoma. Diagn Cytopathol. 2015 Aug;43(8): 659-63.

168 Jayaram G, Mun KS, Elsayed EM, Sangkar JV. Interdigitating dendritic reticulum cell sarcoma: cytologic, histologic and immunocytochemical features. Diagn Cytopathol. $2005 \mathrm{Jul} ; 33(1): 43-8$.

169 Vicandi B, Jiménez-Heffernan JA, LópezFerrer P, Viguer JM. Fine needle aspiration cytology of follicular dendritic cell sarcoma. A case report. Acta Cytol. 2000 Nov-Dec; 44(6):1106-10.
170 Ryley NG, Bastert J, Ferguson DJ, Payne MJ Follicular dendritic cell sarcoma of lymph node-report of fine needle aspiration (FNA) cytological appearances. Cytopathology. 1999 Oct;10(5):335-40.

171 Fan YS, Ng WK, Chan A, Chan GS, Tsang J, Chim CS, et al. Fine needle aspiration cytology in follicular dendritic cell sarcoma: a report of two cases. Acta Cytol. 2007 Jul-Aug; 51(4):642-7.

172 Dutta A, Arun P, Roy P, Arun I. Cytological diagnosis of follicular dendritic cell sarcoma: A case report and review of literature. Cytopathology. 2018 Oct;29(5):461-7.

173 Ojha SS, Jain R, Meenai F, Nilkanthe R, Haritwal A. Cytomorphological findings of follicular dendritic cell sarcoma on fine-needle aspiration cytology. Acta Cytol. 2018; 62(2):145-50

174 Cibas ES, Ali SZ. The Bethesda system for reporting thyroid cytopathology. Thyroid. 19(11):1159-65. 